\title{
Statistical analysis \\ of the Late Miocene sequences \\ on the southeastern Danube Basin margin based on borehole data
}

\author{
${ }^{1}$ Michal Šujan, ${ }^{1}$ Michal Kováč, ${ }^{1}$ Samuel Rybár, ${ }^{2}$ Katarína Šarinová \\ ${ }^{1}$ Comenius University, Faculty of Natural Sciences, Department of Geology and Paleontology; \\ Mlynskádolina G, 84215 Bratislava, Slovakia; e-mail: miso@equis.sk, kovacm@fns.uniba.sk, samuelrybar3@gmail.com \\ ${ }^{2}$ Comenius University, Faculty of Natural Sciences, Department of Mineralogy and Petrology; \\ Mlynská dolina G, 84215 Bratislava, Slovakia; e-mail: sarinova@fns.uniba.sk
}

(C) 2015 Authors. This is an open access publication, which can be used, distributed and reproduced in any medium according to the Creative Commons CC-BY 4.0 License requiring that the original work has been properly cited.

The strata of lacustrine, deltaic and alluvial sequences of the southeastern Danube Basin (SE DB) deposited during the Pannonian were reached by numerous boreholes. Even though the large amount of available data there are inconsistencies in recent knowledge, concerning distribution of different formations in the basin fill as well as the interpretation of their surficial occurrences. The purpose of this study is to utilize the full strength of available borehole data to characterize the spatial distribution and internal architecture of each penetrated sedimentary formation defined by Kováč et al. (2011).

The used database contains more than 700 boreholes reaching average depth of $300 \mathrm{~m}$, which lithological logs were digitalized according to main grain size in each described stratum and considering the origin of the layer. The resulting database comprises up to 16,000 documented layers. For purposes of the statistical analysis were created (1) pie charts of percentual share of each described lithotype (clays, fine sands, medium and coarse sands, gravels) for individual stratigraphic unit; (2) histograms of the percentual content of coarse (medium to coarse sandy and gravely) layers in a lithological column for each stratigraphic unit; (3) histograms of single unit/stratum thickness for each lithotype in each stratigraphic unit; and (4) interpolated maps of spatial distribution of coarse layers (percentual content) in each stratigraphic unit.

Area of the SE DB, bordered by the Transdanubian Range Mts. (TR), represented before the regression of the Lake Pannon a submerged basement high. Specific depositional conditions occurred, because main input of sediment from the Western Carpathians on the northeast and from the paleo-Danube delta on the northwest fell into the offshore depocenter in the central depression of the DB. Lacustrine strata of the Ivanka Fm. deposited there mainly in a shallow offshore environment contain therefore highly bioturbated clays and silts, while sand or coarser sediment is almost absent. This succession described only from core material and well-logs of deep boreholes is comparable to the Szák Fm. described in the Hungarian part of the basin.

Subsequent regression of the Lake Pannon took place through mentioned deltaic systems prograding from the north. The shelf slope prograded to studied area across the basin floor environment of the central depression at $~ 9.0$ Ma. The deltaic sequence, considered as the Beladice Fm., is widely documented by studied boreholes. It is typical with alternating occurrence of brackish and freshwater to terrestrial mollusk fauna and common layers of 
lignite. Lithological composition of the sequence is highly fine grained: $88 \%$ clays, $6 \%$ silts/very fine sands, $6 \%$ sands. Layers coarser than clays form usually $3-18 \%$ of a lithological column. Majority of both described sandy classes form units 1-9 m thick with mean thickness of 2-6 m. A single rhythm of lithological change, which could be assumed as parasequence according to Sztanó \& Magyar (2007), reaches thickness 10-35 m with most frequent value of ca. $25 \mathrm{~m}$. Based on observed situation we can expect that mouth bars, beach ridges and channels representing the thickest sandy bodies form a minor part of the volume, while the main part of upward coarsening cycles were formed by filling of interdistributary bays and lagoons on a delta plain.

On the basis of used data was identified a distinct sedimentary unit, which underlies the deltaic Beladice Fm. in the transitional zone between the SE DB and the TR, named the complex of shelfal sands. The strata consist of sublittoral Congeria czjzeki mollusk alternated with littoral fauna. Average lithology of the complex consists of 57\% clays, $16 \%$ fine sands, $22 \%$ medium and coarse sands and $5 \%$ gravels. However, the complex is laterally variable and single borehole may consist of up to $90 \%$ of sandy and gravely layers. The thickness of individual sandy unit is unclear due to amalgamation. Described lithology is interpreted as a result of sedimentary trap formed between deltaic lobes on the north and partially subaerial exposed islands of the TR on the south. While the deltaic Beladice Fm. contains almost no gravely layers, the gravel described in the complex was probably derived from the TR.

Distinguishing the alluvial Volkovce Fm. from the underlying deltaic Beladice Fm. could be concluded by absence of the brackish mollusk fauna, but it is difficult to exclude the possibility of missing information. The alluvial sequence consists of significantly lower portion of coal layers. Clays form $79 \%$, fine sands $6.5 \%$, medium and coarse sands $14 \%, 0.5 \%$ gravels. Individual well profile usually consists of $5-30 \%$ sandy and gravely layers. Medium and coarse sandy bodies reach thickness 3-15 $\mathrm{m}$ with mean thickness of 5-11 $\mathrm{m}$ and fine sands form bodies 1-8 $\mathrm{m}$ thick. We can assume that the main portion of the medium and coarse sandy deposits in studied alluvial sequence is bound to meandering channel belts ca. $8 \mathrm{~m}$ thick, which are occasionally amalgamated. The few meters thick sandy units represent levees and crevasse splays. These defined alluvial facies associations could be distinguished on outcrops while trend analysis of several well-logs indicates their occurrence in a sedimentary column. Spatial correlation of sedimentary units in wells indicates prevailing orientation of sandy bodies in NW-SE direction, while paleocurrent analysis from field denotes direction from $\mathrm{N}$ and NW. The majority of documented sandy bodies are located in the western part of the studied area.

The boundary between deltaic and alluvial sequences is despite the wealth of data not easy to correlate. The similarity of depositional processes and resulting lithofacies of both successions lead to conclusion that interpreting an outcrop assignment to formation based on lithofacies without precise paleontological analysis and control by boreholes could be dubious.

The work was financially supported by the Slovak Research and Development Agency under the contracts No. APVV 0099-11 and APVV 0625-11. Reviewers Ladislav Vizi and Juraj Janočko are thanked for their constructive comments.

\section{REFERENCES}

Kováč M., Synak R., Fordinál K., Joniak P., Tóth Cs., Vojtko R., Nagy A., Baráth I., Maglay J. \& Minár J., 2011. Late Miocene and Pliocene history of the Danube Basin: inferred from development of depositional systems and timing of sedimentary facies changes. Geologica Carpathica, 62, 6, 519-534.

Sztanó O. \& Magyar I., 2007. Deltaic parasequences on gamma logs, ultra-high resolution seismic images and outcrops of Lake Pannon deposits. Joannea Geologie und Paläontologie, 9, 105-108. 